\title{
The Role of Micronutrients to Support Immunity for COVID-19 Prevention
}

\author{
Mukhtar H. Ahmed ${ }^{1}$ (D) A Arez Hassan ${ }^{2} \cdot$ Judit Molnár $^{3}$
}

Received: 5 July 2021 / Accepted: 7 August 2021 / Published online: 2 September 2021

(c) The Author(s) 2021

\begin{abstract}
The World Health Organization declared the novel coronavirus, named as SARS-CoV-2, as a global pandemic in early 2020 after the disease spread to more than 180 countries leading to tens of thousands of cases and many deaths within a couple of months. Consequently, this paper aims to summarize the evidence for the relationships between nutrition and the boosting of the immune system in the fight against the disease caused by SARS-CoV-2. This review, in particular, assesses the impact of vitamin and mineral supplements on the body's defence mechanisms against SARS-CoV-2. The results revealed that there is a strong relationship between the ingestion of biological ingredients like vitamins $\mathrm{C}-\mathrm{E}$, and minerals such as zinc, and a reduction in the effects of coronavirus infection. These can be received from either nutrition rich food sources or from vitamin supplements. Furthermore, these macromolecules might have roles to play in boosting the immune response, in the healing process and the recovery time. Hence, we recommend that eating healthy foods rich in vitamins $\mathrm{C}-\mathrm{E}$ with zinc and flavonoids could boost the immune system and consequently protect the body from serious infections.
\end{abstract}

Keywords Minerals $\cdot$ Nutrition $\cdot$ Vitamins $\cdot$ SARS-CoV-2 $\cdot$ Supplements

\section{Introduction}

A new generation of coronavirus was detected in December 2019 ; it is similar to other generations of coronavirus such as MERS-CoV and SARS-CoV which are known to cause Middle East respiratory syndrome (MERS) and severe acute respiratory syndrome (SARS) in humans, respectively. The new coronavirus disease, which is known as COVID-19, is caused by the novel SARS-CoV-2 and can cause severe pneumonia and is dramatically more infective (Corman et al. 2019). The coronavirus is affecting almost all countries and territories around the world. At the time of writing, around 193 million cases of COVID-19 had been confirmed, and from which 4.2 million deaths had resulted.

Mukhtar H. Ahmed

ahmed-m@email.ulster.ac.uk

1 Sisaf Nanotechnology Drug Delivery, Ulster University, Belfast BT37 0QB, UK

2 School of Medicine, Queen's University, Belfast BT9 7BL, UK

3 Faculty of Agricultural and Food Sciences, Széchenyi István University, 9200 Mosonmagyaróvár, Hungary
Coronaviruses are enveloped viruses that possess a single-stranded, positive-sense RNA with a genome ranging from 26 to $32 \mathrm{~Kb}$, the largest among all recognized RNA. Coronaviruses can be classified into four genera: alpha, beta, gamma and sigma coronavirus. Among these genera, the $\alpha$-coronaviruses and $\beta$-coronaviruses mainly infect mammals and generally lead to respiratory disease in humans and gastritis in animals (Cui et al. 2019). Currently, there are many strains of coronaviruses that infect humans including HCoVHKU1, HCoV-NL63, HCoV-229E, SARS-CoV and MERS-CoV (Ghinai et al. 2020). The 3C-like protease (3CLpro), formally known as C30 endopeptidase, is the main protease found in coronaviruses. It cleaves the coronavirus polyprotein at eleven conserved sites (Rathnayake et al. 2020). The papain-like protease PLpro is an essential coronavirus enzyme that is required for processing viral polyproteins to generate a functional replicase complex and enable viral spread.

Since the start of the pandemic, several clinical trials have been used to determine the efficacy of certain existing anti-inflammatory and anti-viral drugs as alternative treatment for the disease (Bhatia 2021). Despite these attempts, there are still no drugs which promise to fully cure people from this new disease. Currently, several vaccines are being 
evaluated for their efficacy and safety and for determination of doses for COVID-19, and this requires considerable time for their validation (Ali et al. 2020; Forchette et al. 2021).

The use of alternative herbal remedies has gained prominence following their use in the management of COVID-19 especially in the west where attempts have been made to formulate anti-COVID-19 herbal products. This is a positive approach considering the ever-growing demand for natural, herbal alternatives for drugs and medicines (Chinsembu 2020; Komolafe et al. 2021). Thus, to avoid this disease or to get over the disease quickly, people have been redirecting their focus to natural foods to mimic the medical treatment, as well as to protect themselves from the virus. Following this, nutrition experts have been considering the types of food and diets which have a direct impact on reducing the infection and decreasing the mortality rate.

Healthy eating has been part of a healthy lifestyle and proper nutrition contributes greatly to the strengthening of the immune system. By increasing the body's defences and maintaining it in an excellent condition, the coronavirus can be defeated more easily. Several studies have showed that the lack of quality and/or quantity of micro- and macronutrients (malnutrition) in the diet causes an increase in the morbidity and mortality (Jayawardena et al. 2020). Malnutrition resulted in an increased rate of viral and/or bacterial infections and delayed recovery in the living body. Recent studies have revealed that the importance of optimal nutritional status is necessary to protect against both bacterial and viral infections (Calder et al. 2020). The review focuses on the properties and immunological roles of vitamins $\mathrm{C}, \mathrm{D}$ and $\mathrm{E}$ with zinc and flavonoids to support immunity for prevention of respiratory infections, acute respiratory distress syndrome (ARDS) and COVID-19.

\section{Search Strategy}

Electronic searches were conducted on Google Scholar database Medline and PubMed. A further search was conducted on the World Health Organization's COVID-19 research article database. The search items included coronavirus, SARS-CoV-2, supplements, nutrition and immune system. This review was conducted to analyse the recent literature to show the impact of micronutrition in preventing the coronavirus disease.

\section{Discussion}

\section{Pathogeneses of COVID-19}

Coronavirus are large family enveloped and positive strained RNA viruses that contain the largest known RNA genomes with a length of up to $31 \mathrm{~kb}$. Coronaviruses pathogens cause various diseases in mammals (humans and animal) and birds, including the recently isolated severe acute respiratory syndrome coronavirus (SARS-CoV). The SARS-COV-2 S-protein is similar is that of SARS-COV, while the affinity of SARS-COV-2 for (ACE-2) receptor is approximately 20 times higher than that of the SARS S-protein (Ahmed and Hassan 2020). The results found that the immune cells such as monocytes and natural killer (NK) cells respond more strongly to viral infection. Adult respiratory distress syndrome (ARDS) starts to develop about after 7 days of the disease because of an explosive host immune response due to uncontrolled viral replication.

The SARS-CoV-2 infection has sequential phases, with the progression, from one phase to the next, causing the deterioration in the health of the patient. After the first 5 days of incubation in the body, the virus directly affects the respiratory system, the patient begins to show severe hypoxemia (a decrease in the partial pressure of oxygen in the blood) which later causes abnormally low oxygen content in the tissues and/or organs (Siddiqi and Mehra 2020). In the second phase of infection, granulocyte colony-stimulating factor (G-CSF), inflammatory cytokines and biomarkers like interleukin IL-2, IL-6, IL-7, tumour necrosis factor- $\alpha$ (TNF- $\alpha$ ) macrophage inflammatory protein $1-\alpha, \mathrm{D}$-dimer, C-reactive protein (CRP) and ferritin are markedly elevated in patients who are critically ill (Ahmed and Hassan 2020). In the third phase, patients, who are infected with COVID 19 , are susceptible to developing shock, respiratory failure, cardiopulmonary collapse (Mehta et al. 2020), acute kidney injury (AKI) (McAdams et al. 2021), liver damage, gastrointestinal system tissue damage, blood clots and nervous system damage.

In general, following the viral multiplication, high numbers of reactive species (RS) can be produced, causing an imbalance in cellular redox homeostasis. Consequently, the imbalance of free radicals and antioxidants in the cell (oxidative stress) is caused by the viral infection, enhancing the production of reactive oxygen species (ROS) (Mrityunjaya et al. 2020; Camini et al. 2017). Therefore, changes in redox homeostasis in infected cells are one of the important events in the pathogenesis in all phases of the disease (Khomich et al. 2018). Besides the depression of the immune system, the lungs are the main organ which are most affected by coronavirus disease, as this virus mainly infects the upper and lower respiratory systems. In addition to that, some literature has revealed that acute kidney injury (AKI) is also associated with coronavirus disease (Kunutsor and Laukkanen 2020). A recent study showed that COVID-19 directly infects the heart and causes the myocardial injury, due to the virus binding to ACE- 2 receptors in the cardiovascular system (Madjid et al. 2020). Furthermore, the damage of other systems like the central nervous system, circulatory 
system, urogenital system and the digestive system have been recorded among severely ill patients with COVID-19 (Zhang et al. 2020). As well as that following the recovery from COVID-19, many patients, particularly the elderly and those with underlying medical conditions, are most likely to experience lingering COVID-19 symptoms like shortness of breath, muscle pain, headache fatigue and join pain. This condition is called long-COVID-19 syndrome (Ayoubkhani et al. 2021).

To reduce the above symptoms and shorten the recovery time of this disease and others, the nutrition experts have recommended eating healthy foods like those high in vitamins and minerals such as fresh vegetables and fruits, claiming that this could have significant impact in improving health and reducing the negative effects of the disease, during and post COVID-19 infection. This is because many micronutrients are able to protect or initiate the recovery of the damaged organs, caused by COVID-19, through boosting the immune system and fighting this virus during infection stage. As aforementioned, acute kidney injury (AKI) incidents occur in patients with COVID-19. This can be higher in some cases due to the higher prevalence of comorbid conditions like chronic kidney disease (CKD), diabetes and hypertension (McAdams et al. 2021). On the other hand, the results reported that anaemia is associated with AKI and its interstitial damage. This occurs as the injured kidney cannot make enough erythropoietin hormone (EPO); this hormone is required to stimulate haematopoiesis (formation of new red blood cells), and thus red blood cell count drops leading to anaemia. This disease causes additional problems to the patient include increasing the cardiac output, reduce oxygen utilization level, as well as affecting the responsiveness of the body's immunity.

\section{Micronutrients in Immunity}

The human immune system is essential for our survival. The immune system helps to protect our body against diseases caused by virus, bacteria and parasites by recognizing and responding to antigens, the substances that cause the immune system to produce antibodies against it. The immune system is divided up into two parts: the innate or (non-specific) immune system and the adaptive or (specific) immune system. They consist of different cells which work together properly to protect our bodies from foreign invaders by each being responsible for the destruction of different types of pathogens. The innate immunity response, particularly the type-I interferon (IFN), provides a general defence against harmful materials. This function is described as a first line of defence in the immune response. The adaptive immune system produces antibodies and uses them to fight certain foreign bodies that our body has previously encountered. The most essential components of the adaptive immune system are CD4+T cells, $\mathrm{CD} 8+\mathrm{T}$ cells and $\mathrm{B}$ cells (antibodies) (Nawsherwan et al. 2020).

In the case of COVID-19 attack, the innate immune system quickly recognizes the infection and is triggered within a couple of hours of infection. The innate immune response tries to directly inhibit the virus replication within infected cells and produces a local environment rich in IFN, in addition, to prime the adaptive immune response. After the priming effect, adaptive immune response takes 6-10 days to produce enough cells to control a viral infection (Sette and Crotty 2021).

\section{Vitamin C}

The water-soluble micronutrient vitamin $\mathrm{C}$, also known as ascorbic acid or ascorbate, has potential biological activity in the human body. It has the chemical formula $\mathrm{C}_{6} \mathrm{H}_{8} \mathrm{O}_{6}$. The chemical designation for ascorbic acid is 2-oxo-L-theohexono-4-lactone-2, 3-enediol. Ascorbic acid is a near planar five-member ring with two chiral centres that resolves into the four stereoisomers. As an electron donor, ascorbic acid acts as a cofactor for several mammalian enzymes that mediate a variety of essential biological functions, including wound healing and collagen synthesis (Messina et al. 2020). In adults, the requirement for vitamin $C$ is $75-90 \mathrm{mg}$ per day and a deficiency leads to impaired collagen synthesis, contributing to the more severe symptoms of scurvy. Vitamin C plays a vital role in the protection of cellular components like nuclease, protein, lipids and as well cell membranes from the oxidizing effects of free radical induced damage (Name et al. 2020). Furthermore, their activity is not only intracellular, but vitamin $\mathrm{C}$ is also responsible for immune activation following exposure to chemical and biological toxins. Another biochemical role of vitamin $\mathrm{C}$ is to act as an antioxidant (a reducing agent) by donating electrons to various enzymatic and non-enzymatic reactions. This activity converts vitamin $\mathrm{C}$ to an oxidized state, either as semi-dehydroascorbic acid or dehydroascorbic acid. These compounds can be restored to a reduced state by glutathione and NADPH-dependent enzymatic mechanisms (Scheme 1).

Several clinical studies have shown the ability of vitamin $\mathrm{C}$ to increase serum concentrations of iron and haemoglobin. Vitamin $\mathrm{C}$ is active in weak acidic and neutral ( $\mathrm{pH}$ 4.5-7.4) conditions so vitamin $\mathrm{C}$ can act to increase the solubility of iron in the small intestine (duodenum) through chelation of ascorbic acid and iron to form iron chelate complex (Milman 2020). This is essential to ensure that iron-deficiency anaemia does not form, as this disease would be detrimental to those with COVID-19, a disease that already affects oxygen levels. Furthermore, ascorbic acid has the ability to protect against lipid peroxidation (LPO) by acting as a scavenger for reactive oxygen species and by causing a one-electron 


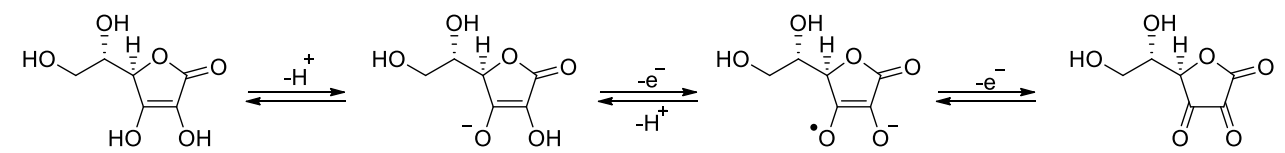

Scheme 1 The structure of ascorbic acid and the main products of redox reactions. Ascorbic acid (AscH2); ascorbate anion (AscH $\left.{ }^{-}\right)$; ascorbyl radical $\left(\right.$ Asc $\left.^{-}\right)$; dehydroascorbic acid (DHA)

reduction of lipid hydroxyl radicals through the redox cycle of tocopherol (Traber and Stevens 2011).

In studies, assessing the link between vitamin $\mathrm{C}$ and various viral infections has shown positive results. In terms of the influenza virus, Kim and his group (Kim et al. 2013) demonstrated that vitamin $\mathrm{C}$ possesses a significant role in the in vivo antiviral immune response against the $\mathrm{H} 3 \mathrm{~N} 2$ influenza virus, via increased production of type I interferons (IFN- $\alpha / \beta$ ), and their number increases within first couple of days after inoculation with a virus and, therefore, plays an essential role in the prohibition of viral pathogenesis. Furthermore, administration of vitamin $\mathrm{C}$ to patients with pneumonia induced by influenza virus (H1N1) showed a markedly reduced expression level of susceptibility genes, including interferon regulatory factor 3 (IRF3), mitochondrial antiviral signalling (MAVS), with an increase in nuclear factor kappa light chain enhancer of activated B cells (NF-KB) (Cai et al. 2015). Therefore, it might be logical to infer that the maintaining sufficient levels of vitamin $C$ in the plasma either by the continuous uptake through the diet or supplement could effectively prevent in vivo pathogenesis of influenza virus at the initial stage of viral infection.

Vitamin $\mathrm{C}$ has shown to be effective against infections caused by other viruses, for instance, endothelial cells and human foreskin fibroblast were treated with ascorbic acid before cytomegalovirus (CMV) infection; there was a crucial decrease in the cellular viral load and the expression of viral antigen. This was explained by the immunomodulatory effects of ascorbic acid (Biancatelli et al. 2020a, b). Consequently, to reducing the level of infection, vitamin $\mathrm{C}$ has also been shown to be linked to a quicker recovery from fever, chills and chest pain as well (Ran et al. 2018). These results correlated with a meta-analysis study carried out on elective cardiac surgery patients, where (1-3) g/day of vitamin C was administered and resulted in a shorter the length of ICU stay, and the time mechanical ventilation was required (Hemilä and Chalker 2019).

Additionally, the earlier evidence of vitamin $\mathrm{C}$ to shorten the intensive care unit (ICU) stay of patients in critical care with conditions like respiratory failure and ARDS gives the opportunity to study the function of vitamin $\mathrm{C}$ in similar cases related to COVID-19 (Singh et al. 2020). Furthermore, in a systematic review of eight randomized controlled trials in 3135 children aged 3 months to 18 years, ascorbic acid administration showed to decrease the duration of upper respiratory tract infection by 1.6 days (Vorilhon et al. 2019). In a phase 1, randomized double-blind, placebo-controlled study, vitamin $\mathrm{C}$ infusion rapidly decreased the procalcitonin levels, and proinflammatory biomarkers $\mathrm{C}$-creative protein (CPR) inhibited a rise in the level of thrombomodulin resulting in reduced vascular damage (Nawsherwan et al. 2020). A recent study demonstrated that administration of highdose vitamin $\mathrm{C}$, in combination with conventional treatment, such as anti-inflammatory (corticosteroids), antiviral and antibiotic drugs, was a safe and effective treatment for severe cases of patients with respiratory viral infection (Hoang et al. 2020). A further clinical study found that $4 \mathrm{~g}$ of vitamin C per day for 4 weeks in 594 severely ill surgical patients crucially reduced the incidence of acute lung injury and organ failure in comparison with patients receiving only a mechanical ventilation (Nathens et al. 2002). As a result, it is no surprising that the performance of high dose vitamin $\mathrm{C}$ treatment could significantly decrease the requirement for high doses of orthodox pharmaceutical drugs that may be immunosuppressive and cause disease complications. Therefore, vitamin $\mathrm{C}$ supplements promising to boost the immune system and promote resistance against COVID-19 infection. Hence, taking natural foods rich in vitamin $\mathrm{C}$ such as fresh vegetables and fruits like citrus fruits, strawberries, kiwi and cauliflower (Kalantar-Zadeh and Moore 2020) (Table 1), during COVID-19 pandemic, might be worthwhile. This is because it will help increase iron absorption, needed to prevent anaemia, and ensure adequate oxygen transport in the body, and help boost the immune system.

\section{Vitamin D}

Vitamin D is a fat-soluble steroid hormone precursor that comes in two major forms: ergocalciferol which has the molecular formula, $\mathrm{C}_{28} \mathrm{H}_{44} \mathrm{O}$ (vitamin $\mathrm{D}_{2}$ ), and cholecalciferol which has the molecular formula, $\mathrm{C}_{27} \mathrm{H}_{44} \mathrm{O}$ (vitamin $D_{3}$ ). Vitamin $D_{2}$ is the active form of vitamin $D_{3}$ and is produced in the kidney, while vitamin $\mathrm{D}_{3}$ is produced in the skin from conversion of 7-dehydrocholesterol by exposure of the sunlight. Ergocalciferol or vitamin $\mathrm{D}_{2}(\mathbf{1})$ and cholecalciferol or vitamin $\mathrm{D}_{3}(\mathbf{2})$ are equivalent for vitamin $\mathrm{D}$ production, as both forms appear to have similar efficacy in ameliorating rickets and reducing the incidence of falls in elderly patient. The metabolism and activation of vitamin D occur in the liver and kidney and magnesium as a co-factor. The liver 
Table 1 Recommended daily amount and the sources of vitamins C, D and E with zinc and flavonoids

\begin{tabular}{|c|c|c|c|c|}
\hline \multirow[t]{2}{*}{ Macronutrients } & \multirow{2}{*}{$\begin{array}{l}\text { RDA } \\
\text { In adults }\end{array}$} & \multirow[t]{2}{*}{ Overdosage } & \multicolumn{2}{|l|}{ Nutrient sources } \\
\hline & & & Plant & Animal \\
\hline $\begin{array}{l}\text { Vitamin C } \\
\text { (ascorbic acid) }\end{array}$ & $\begin{array}{l}\text { W:75 mg } \\
\text { M: } 90 \mathrm{mg} \text { (Institute of } \\
\text { Medicine-US 2000) }\end{array}$ & > 2000 mg/day & $\begin{array}{l}\text { Fruits: Blackcurrants, kale, } \\
\text { citrus fruits (lime manda- } \\
\text { rin, orange), kiwi, } \\
\text { Vegetables: Red pepper, } \\
\text { tomato, broccoli, spinach, } \\
\text { cabbage, strawberry }\end{array}$ & $\begin{array}{l}\text { Low amount of vitamin } \mathrm{C} \text { can } \\
\text { be found in eggs, fish roe } \\
\text { and raw liver }\end{array}$ \\
\hline $\begin{array}{l}\text { Vitamin D } \\
(1,25 \text { cholecalciferol })\end{array}$ & $\begin{array}{l}15 \mu \mathrm{g} / \mathrm{day} \\
\text { (Institute of Medicine-US } \\
\text { 2011) }\end{array}$ & $\begin{array}{l}150 \mathrm{ng} / \mathrm{ml} \text { in blood serum } \\
\text { (Marcinowska-Suchowier- } \\
\text { ska et al. 2018) }\end{array}$ & Edible mushrooms & $\begin{array}{l}\text { Fish, meat, egg, and dairy } \\
\text { like cheese }\end{array}$ \\
\hline $\begin{array}{l}\text { Vitamin E } \\
(\alpha \text {-tocopherol) }\end{array}$ & $\begin{array}{l}15 \text { mg/day } \\
\text { (Péter et al. 2015) }\end{array}$ & $\begin{array}{l}1000 \mathrm{mg} / \text { day (Owen and } \\
\text { Dewald 2021) }\end{array}$ & $\begin{array}{l}\text { Nuts and seeds: hazel- } \\
\text { nut, almonds, peanuts, } \\
\text { sunflower, soya, vegetable } \\
\text { oils, } \\
\text { Fruits: mango, avocado }\end{array}$ & $\begin{array}{l}\text { Low amount of vitamin E can } \\
\text { be found in animal sources }\end{array}$ \\
\hline Zinc & $\begin{array}{l}\text { W: } 10 \mathrm{mg} \\
\text { M: } 15 \mathrm{mg} \text { (Gibson et al. } \\
2016)\end{array}$ & $\begin{array}{l}1.09 \text { to } 1.30 \mu \mathrm{g} / \mathrm{ml}(\text { Agnew } \\
\text { and Slesinger 2021) }\end{array}$ & $\begin{array}{l}\text { Seeds and Nuts, } \\
\text { Legumes: lentils, beans, and } \\
\text { chickpeas } \\
\text { Oa and whole grains }\end{array}$ & $\begin{array}{l}\text { Oysters, red meat, and } \\
\text { poultry }\end{array}$ \\
\hline Flavonoids & $\begin{array}{l}250-400 \mathrm{mg} \text { (Peluso and } \\
\text { Palmery 2015) }\end{array}$ & NA & $\begin{array}{l}\text { Fruits: citrus fruits, berries, } \\
\text { apples, cherries, grapes } \\
\text { and soybeans } \\
\text { Vegetables: onion and leafy } \\
\text { vegetables } \\
\text { Nuts, Tea and Wine }\end{array}$ & \\
\hline
\end{tabular}

Abbreviations: RDA is recommended daily amount, $W$ women, $M$ men

converts cholecalciferol (2) to 25-hydroxy cholecalciferol $\left[25(\mathrm{OH})\right.$ Vit $\left.-\mathrm{D}_{3}\right](\mathbf{3})$. The next step of the metabolism will occur in the kidney through the conversion of $[25(\mathrm{OH})$ Vit$\left.\mathrm{D}_{3}\right]$ to $\left[1,25\right.$ dihydroxy Vitamin $\left.\mathrm{D}_{3}\right](4)$ and $[24,25$ dihydroxy Vit- $\left.\mathrm{D}_{3}\right]$ (Stubbs et al. 2014).

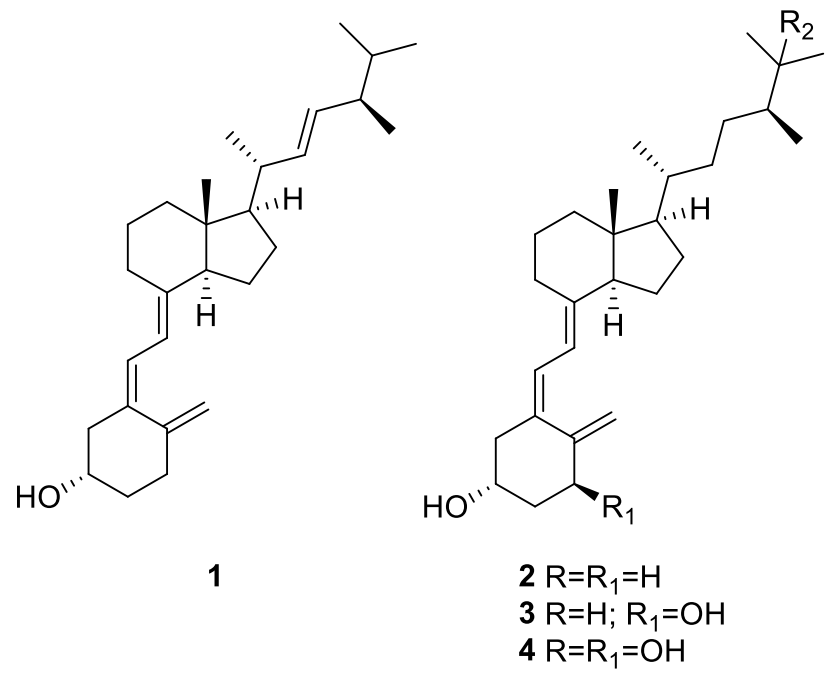

In addition to bone mineralization, vitamin $\mathrm{D}$ is also involved in cellular differentiation and regeneration of several organs. Vitamin D has a number of recently recognized roles within the immune system including endogenously regulating both the innate and humoral immune responses. Vitamin D, produced locally by monocytes, results in a shift in the immune status from proinflammatory to tolerogenic and regulates $\mathrm{CD} 4+\mathrm{T}$-cell responses by suppressing $\mathrm{T}$ helper (Th1) cell function and decreasing proinflammatory cytokines production, as illustrated in Fig. 1 (Bishop et al. 2021). In addition of helping dampen the immune system during a chronic reaction (anti-inflammatory potential), vitamin $\mathrm{D}$ also aids the innate immune cells to engulf and kill viruses or bacteria (Maggini et al. 2018). Furthermore, intake of vitamin D 3 could enhances the amount of Treg cells (T cells) and reduce immunoglobulin-G (IgG) production (Rondanelli et al. 2018). Moreover, recent research studies have also found that 1,25 dihydroxy vitamin $\mathrm{D}_{3}(4)$ is considered as a transcriptional regulator of endothelial nitric oxide synthase, which leads enhanced endothelial nitric oxide (NO) production (Charoenngam and Holick 2020). Vitamin D deficiency in the body can be associated with various disorders, including skeletal deformities, cardiovascular disorders and metabolic syndrome (Uwitonze and Razzaque 2018). There is an inverse relationship between serum 25-hydroxy vitamin D3 levels and the upper respiratory tract viral infection. This might 
Fig. 1 The anti-inflammatory and tolerogenic activity of Vitamin D. Reproduced from Chirumbolo et al. 2017

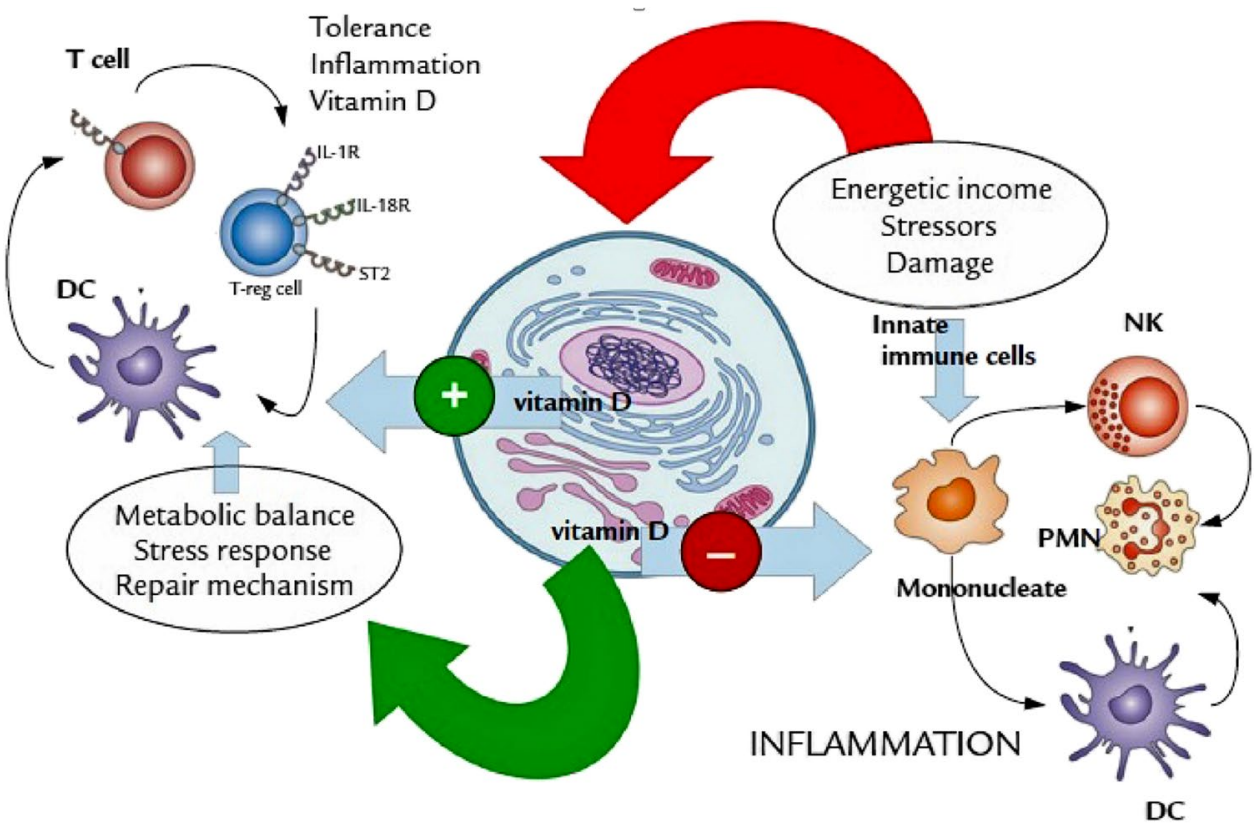

help conclude that the vitamin D3 supplements are associated with a lower risk of acute respiratory infections caused by COVID-19 (Shakoor et al. 2021). Vitamin D, similarly, to vitamin $\mathrm{C}$, plays a key role in the formation and maintenance of epithelial barriers as lung tissue.

Pludowski and his group have suggested that vitamin $\mathrm{D}_{3}$ possess the ability to inhibit transcription of HIV RNA which is normally upregulated by TNF- $\alpha$ (Pludowski et al. 2018). Vitamin $D_{3}$ has a key role in the regulation of both innate immune response (the first line of defence) and adaptive immune response, indicating that taking sufficient amount of vitamin $\mathrm{D}_{3}$ might protect patients with SARSCoV-2 through blocking the activity of pro-inflammatory cytokines such as tumour-necrosis-factor (TNF- $\alpha$ ), IL-6 production and interferon gamma (IFN $\gamma$ ) (Daneshkhah et al. 2020). On the other hand, vitamin D has been shown to exert an antioxidant effect by causing the upregulation of the nuclear factor erythroid 2-related factor 2 (NRF-2), a master inducer of antioxidant responses (Kim et al. 2020) which results in decreased ROS as well as the virus production (Mrityunjaya et al. 2020). Furthermore, in a randomized controlled trial, they found that a high vitamin D supplementation of $(100,000) \mathrm{IU} / \mathrm{month}$ helps in decreasing the incidence of acute respiratory infections (Ginde et al. 2017). This result represents a good evidence to suggest that it may lead to a reduction in mortality in patients with COVID19-associated ARDS, which is normally caused by increased expression of pro-inflammatory cytokines (Costela-Ruiz et al. 2020). Interestingly, a clinical study found that normal serum vitamin $\mathrm{D}_{3}$ may decrease SARS-CoV-2 infection severity, the time spent in intensive care units and mortality by around 50\% (Kmietowicz 2020). A recent study revealed that vitamin D supplementation can lower the incidence, severity and risk of death from COVID-19 (Grant et al. 2020).

Therefore, sufficient vitamin D supplementation can enhance the immune system to prevent COVID-19 infection. The recommended daily allowance of vitamin $\mathrm{D}$ for adults is $15 \mu \mathrm{g}$ per day (Institute of Medicine-US 2000). Thus, the consumption of foods rich in vitamin D and/or taking supplements, especially by those who live in northern countries who lack adequate sun light, are recommended to reduce the effects caused by the coronavirus infection. Foods that are particularly rich in vitamin D includemeat, egg, fish and dairy products such as cheese.

\section{Vitamin E}

Vitamin E occurs in a variety of related fat-soluble isoforms, known as vitamers that include four tocopherols and four tocotrienols. Both the tocopherols and tocotrienols occur in $\alpha, \beta, \gamma$ and $\delta$ forms, as determined by the number and position of methyl groups on the chromanol ring. All eight of these vitamers feature a chromane double ring, with a hydroxyl group that can donate a hydrogen atom to reduce free radicals, and a hydrophobic side chain which allows for penetration into biological membranes (Niki and Abe 2019). Among those, only $\alpha$-tocopherol (5) meets the human requirements for the active vitamin $\mathrm{E}$ isoform (Jovic et al. 2020). Of the many different forms of vitamin E, $\gamma$-tocopherol is the most common form found in the North American diet, but $\alpha$-tocopherol is the most biologically active. Palm oil is a source of tocotrienols. 


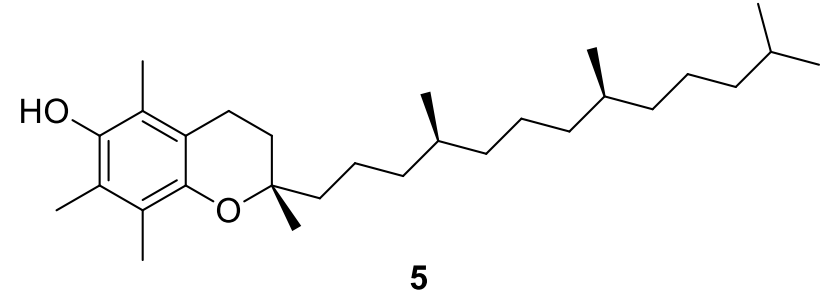

$\alpha$-Tocopherol (5), a potent chain-breaking antioxidant, is an effective peroxyl radical scavenger; these properties play a significant role in protecting the nervous tissues and erythrocyte membranes as well (Traber and Atkinson 2007). Most of free radicals are produced from the metabolic reactions of unsaturated fats in the cell membranes, resulting in peroxidative decomposition. As it has been mentioned above, vitamin $\mathrm{E}$ supports the ability of vitamin $\mathrm{C}$ to protect against lipid peroxidation (LPO) (Halliwell and Gutteridge 2015).

Similar to flavonoids and ascorbic acid, $\alpha$-tocopherol (5) is considered a strong antioxidant, which is capable of neutralizing reactive oxygen species (ROS) and can block acute neutrophil inflammation in the lungs (Sahin et al. 2020). Deficiency of $\alpha$-tocopherol results in higher levels of lipid peroxidation; this has been confirmed in trials by the inverse relationship between $\alpha$-tocopherol and plasma lipoperoxidase in acute respiratory disease syndrome (ARDS) patients. Results from randomized clinical studies have demonstrated that there is a significant relationship between $\alpha$-tocopherol supplementation and a reduction in the incidences of upper respiratory tract infections in elderly nursing home residents (Meydani et al. 2004). $\alpha$-Tocopherol acts via an antioxidant pathway to increase mitogenic lymphocyte response, enhance the number of $\mathrm{T}$ cells, increase natural killer (NK) cells activity (NK cells act to kill viral infected cells) (Sharrock 2019), and enhance IL-2 cytokine (also called T-cell growth factor, IL-2-related family that functions to stimulate T-cell growth) (Adolfsson et al. 2001). In addition, $\alpha$-tocopherol supplementation showed the ability to enhance the resistance to respiratory infections (Kieliszek and Lipinski 2020). Although vitamin E appears to have some beneficial roles in immunity, there is limited clinical information on the effects of vitamin $\mathrm{E}$ in humans with COVID-19 infection, though patients are encouraged to have adequate intakes of all antioxidant nutrients. Vitamin E cannot be synthesized in the body so must be consumed through foods. Nuts, seeds and vegetable oils are the best source of vitamin $E$. The recommended daily dose of vitamin $\mathrm{E}$ is around $15 \mathrm{mg}$ (Péter et al. 2015).

\section{Zinc}

Zinc is considered a crucial trace mineral in the human body followed by iron. It is an essential cofactor for the synthesis and functioning of several proteins. It is a potent immunoregulatory agent, cytoprotectant and growth cofactor. In addition to that, it possesses strong anti-inflammatory, antiapoptotic and antioxidant stress agent activity (Zalewski et al. 2005), as it acts as a cofactor for around three hundred antioxidant enzymes (which convert the superoxide to hydrogen peroxide) in human body.

In terms of zinc's role in antiviral immunity, zinc is involved in the innate immune response. Firstly, the antioxidant and anti-inflammatory activity of zinc makes it necessary for the barrier function of the mucosal epithelium. In addition, zinc controls the tight junction proteins, essential for ensuring the integrity of the mucosal membrane (Mossink 2020). A compromise in the integrity of the mucosa could exacerbate viral inflammation. This causes alveolar oedema, secondary to high weight protein and water exudation which may result in ARDs (Skalny et al. 2020). Furthermore, zinc regulates the proliferation, differentiation, maturation and functioning of T cells, B cells and eosinophils by modifying various signalling pathways, including T-cell receptor (TCR) signals, B cells receptor (BCR) and nuclear factor kappa B cells (NF-kB) signalling pathways, which plays a key role in controlling transcription of DNA, cytokine production and cell survival (Suzuki et al. 2021).

Wessels et al. (2017) demonstrated that generation of cytokine and ROS depend on zinc availability in the cell. ROS play a significant role in physiological and pathophysiological signal transduction (Steven et al. 2018). Zn deficiency resulted in a serious alteration of lung epithelial cell function through up-regulation of TNF $\alpha, \operatorname{IFN} \gamma$ and FasR signalling and cellular apoptosis (Skalny et al.2020). In vitro studies have shown that zinc therapy leads to increase in interferon- $\alpha$ secretion (IFN $\alpha$ ) by leucocytes. This effect aids immune activation during a viral infection (Skalny et al. 2020). Studies demonstrated that oral supplementation of $\mathrm{Zn}$ decreases the incidence of acute respiratory infections by $35 \%$. Furthermore, zinc reduces the duration of flu-like symptoms by 2 days and in addition improves the rate of recovery (Mrityunjaya et al. 2020). It modulates cytokine production, motivates proliferation of CD8 + T cells, develops $\mathrm{T}$ lymphocyte and prohibits free radical-induced injuries during the inflammatory response (Nawsherwan et al. 2020). Recent physiological studies have revealed that zinc is a strong inhibitor of HIV reverse transcriptase (RT) enzyme; this is also known as RNA-dependent DNA polymerase (Read et al. 2019). Recent investigations demonstrated that zinc is strongly involved in the modification and posttranslational process of proteins, when phosphorylation (addition of $\mathrm{PO}^{-}$group 
on the surface of protein) is occurring, and ubiquitination which play a crucial role in many of the steps in innate immunity (Nchioua et al. 2020). The details of antiviral activities of zinc are illustrated in Fig. 2.

An in vitro study demonstrated that zinc inhibits the replication of coronavirus-19 in cell cultures (te Velthuis et al. 2010). In addition to that, recent study illustrated that zinc finger antiviral protein (ZAP), which efficiently targets $\mathrm{CpG}$ dinucleotides in viral RNA, significantly inhibits COVID-19 replication (Nchioua et al. 2020).

Mossink et al. suggested that increasing the level of zinc in the diet in all ages could play a significant role in controlling COVID-19 disease (Mossink, 2020).

Zinc deficiency has also been linked to an exacerbation of the reduction in smell and taste, which occurs in COVID-19 patients (Joachimiak and Joachimiak 2021). During an infection, an organism can mobilize zinc reserves for priority functions, such as those associated with the immune system. This leads to a decrease in zinc levels and possibly in the loss of zinc supply to other less essential functions, such as the maintenance of smell and taste. The recommended dietary allowance dose of $\mathrm{Zn}$ from various studies ranges from $10 \mathrm{mg}$ up to $40 \mathrm{mg}$ per day (Gibson et al. 2016). Oysters are considered the best source of zinc, following that, red meat, poultry, nuts, seed and legumes are also good sources of zinc (Table 1).

\section{Flavonoids}

Flavonoids are a large family of polyphenolic compounds produced by plants. As a result of their lower redox potentials under the physiological conditions $(-30 \mathrm{mV}$ to $+60 \mathrm{mV}$ ), they can oxidize automatically producing at least three or more oxygen free radicals (Eleonora et al. 2011). The action of free radicals leads to cellular membrane damage which causes cell death. Due to the capacity of the phenolic rings to promote the electron donation and hydrogen atom transfer to free radicals, acting as free radical scavengers, reducing agents and quenchers of single oxygen formation (Diniz et al. 2020), flavonoids possess potent physiological activities such as anticancer, antibacterial, anti-inflammatory and immunomodulatory abilities (Liskova et al. 2020). The antioxidant activity of flavonoids results in an increase in the levels of antioxidant enzymes which promotes a reduction of oxidative stress and cell damage as illustrated in Fig. 3.

Quercetin, 3,3',4'5,7-pentahydroxyflavone (6), is found in many plants and foods, such as red wine, onions, green tea, apples, berries, Ginkgo biloba, St. John's wort, American
Fig. 2 The various stages of viral replication cycles that are inhibited by zinc. Reproduced from Jothimani et al. 2020

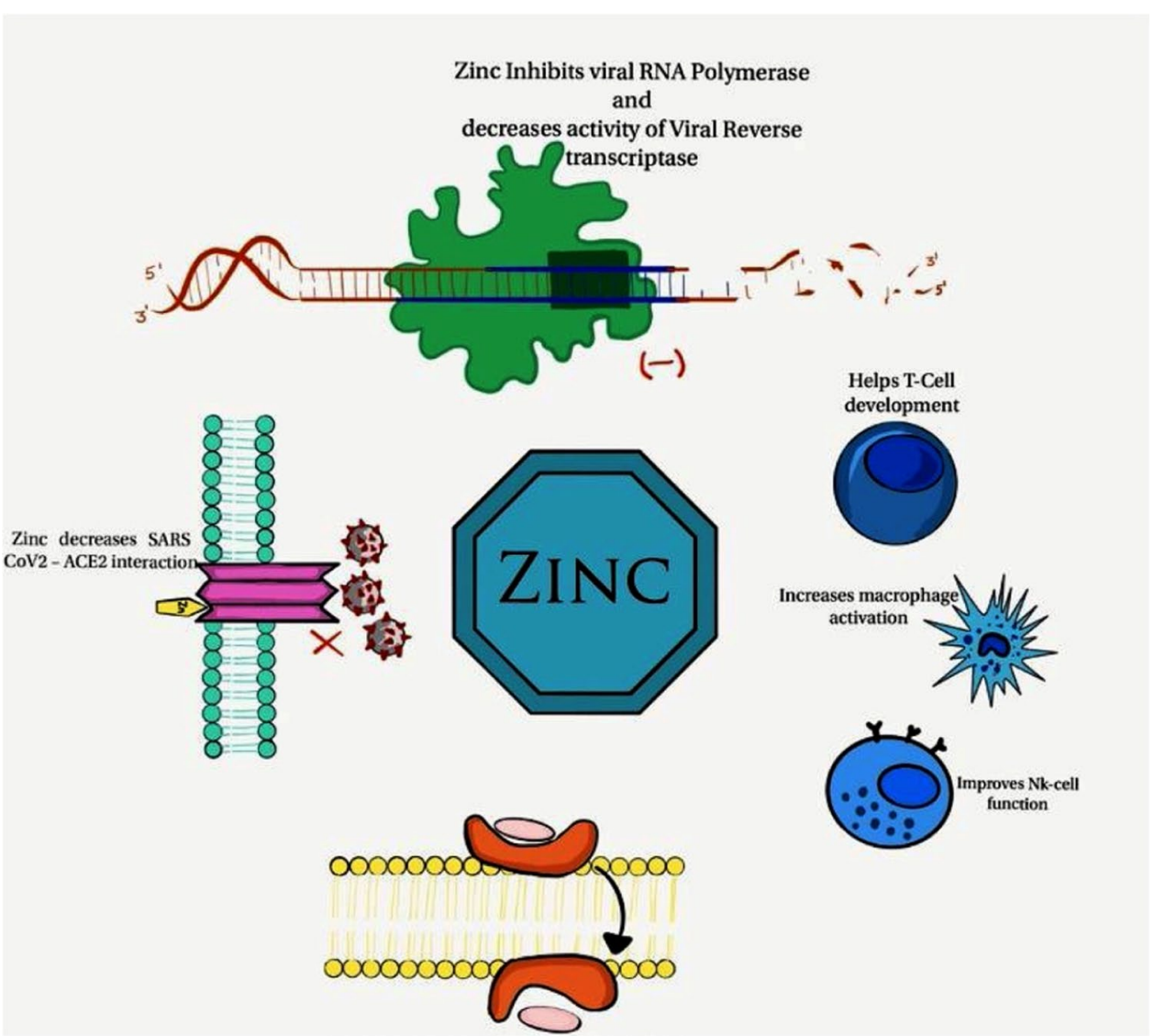


Fig. 3 Antioxidant activity of active redox natural compounds as flavonoids (scavengers of ROS) by promoting an increase in the levels of antioxidant enzymes (SOD, CAT and GPx) and nonenzymatic antioxidants (vitamins $\mathrm{C}$ and $\mathrm{E}$ and $\mathrm{GSH}$ ) and a reduction of oxidative stress, and cell damage. Abbreviations: superoxide dismutase (SOD), catalase (CAT), glutathione peroxidase (GSH), thiobarbituric acid reactive substance (TBARS), malondialdehyde (MDA), reactive oxygen species. Reproduced from Diniz et al. 2020

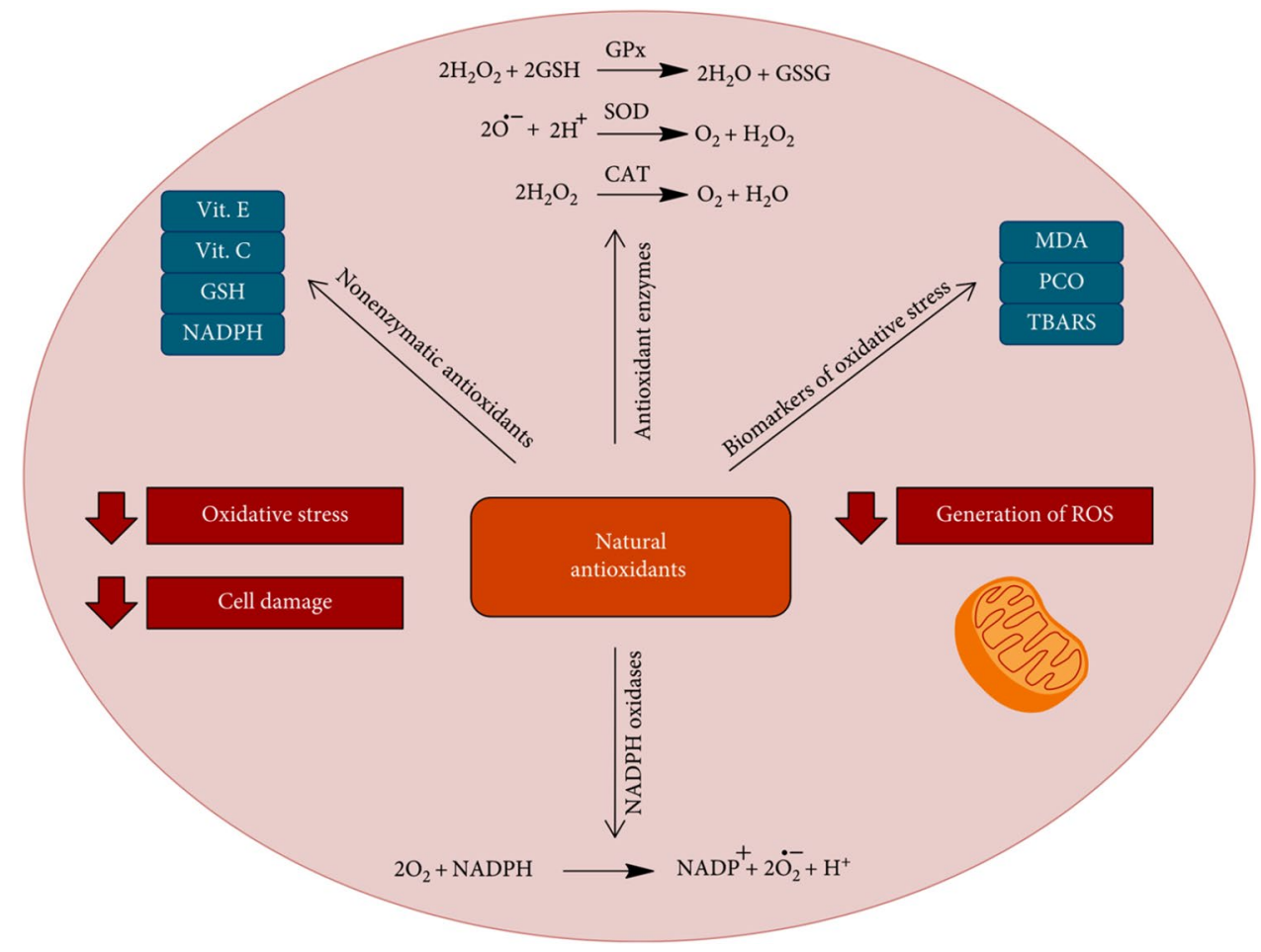

elder and others. Buckwheat tea has a large amount of quercetin. Quercetin shows antioxidant activity at a concentration of $10 \mu \mathrm{mol} / \mathrm{l}$ in HepG 2 cells, inhibiting oxidative stress promoted by $\mathrm{H}_{2} \mathrm{O}_{2}$; promotes an increase in superoxide dismutase (SOD), catalase (CAT), and glutathione peroxidase (GSH$\mathrm{PX}$ ); and reduces lipid peroxidation in rats with chronic prostatitis/chronic pelvic pain syndrome by anti-inflammatory and antioxidative activities through down-regulating nuclear factor kappa (NF-kB) and mitogen-activated protein kinase (MAPK) signalling pathways (Meng et al. 2018). Moreover, quercetin improves sepsis-induced acute lung injury in rats, by reducing lipid peroxidation and inflammation and increasing SOD and CAT levels. In addition, flavonoids showed significant reduction in interleukin (IL)- 6 and IL- $1 \beta$ in lung tissue which are the proinflammatory cytokines (Rungsung et al. 2018). It has also been demonstrated that flavonoids are very strong nitric oxide (NO) producers (Van Acker et al. 1995). Nitric oxide is able to deactivate the coxsackievirus protease $3 \mathrm{C}$ enzyme, which is needed for the replication of coxsackievirus. This mechanism of inhibition of protease activity leads to a decrease in the viral life cycle (Saura et al. 1999).<smiles>O=c1c(O)c(-c2ccc(O)c(O)c2)oc2cc(O)cc(O)c12</smiles>

6

Antiviral properties of flavonoids have been demonstrated in numerous investigations. Castrillo and Carrasco (1987) reported that flavonoids able to bind to specific proteins during the transcription process of viral RNA. For example, 3-O-methylquercetin, 3',4',5,7-tetrahydroxy3-methoxyflavone, inhibits selectively poliovirus RNA synthesis both in infected cells and in cell-free systems. Moreover, in a number of cases, flavonoids can bind to 
the viral capsid protein and modify the virus structure (Lalani and Poh 2020). Flavonoids can act at different stages of coronaviral infection, particularly at the molecular level to inhibit viral growth. Their antiviral activity could be attributed to its inhibitory effects on the enzymatic activity of target cells involved in coronavirus replication. The most important property of flavonoids is that they are able to display angiotensin converting enzyme (ACE2) inhibition activity. As explained above, ACE-2 is an effective receptor for coronavirus. It is found on the surface of the target cells and can strongly bind to the spike protein of coronavirus; this allows the virus to infect the epithelial target cells (Muchtaridi et al. 2020). A recent study demonstrated that flavonoids are able to inhibit both coronavirus protease enzymes 3C-like-protease (3CLpro) and papain-like cysteine protease (PLpro) which play an essential role in viral replication in host membranes (Russo et al. 2020). On the other hand, studies have observed that flavonoids contribute to the reduction of ROS accumulation decelerates the coronavirusactivated apoptotic signalling (Diniz et al. 2020; Godinho et al. 2021). In silico molecular docking studies have been performed to evaluate and validate the inhibitory effect of flavonoids based on the hydrogen-bonding distance between selected amino acid residues of the catalytic site from 3CLpro and PLpro SARS-CoV-2 proteases and flavonoids (Leal et al. 2021).

Finally, a study, assessing the link between ascorbic acid (vitamin C) and flavonoids, showed that synergy occurred as antiviral activity was enhanced. This is potentially due to the capability of vitamin $\mathrm{C}$ to recycle flavonoids and increase its activity in inhibiting viral protein and RAN synthesis (Vrijsen et al. 1987). Recently, based on the clinical trial, it is proposed that the oral administration of $250-500 \mathrm{mg}$ quercetin (6), $500 \mathrm{mg}$ vitamin C for high risk and mild symptomatic subjects twice a day for 7 days and up to $3 \mathrm{~g}$ vitamin $\mathrm{C}$ and $500 \mathrm{mg}$ quercetin twice a day for 7 days in ARDS patients (assisted ventilation/intubation) improves the overall recovery in SARS-CoV-2 subjects (Biancatelli et al. 2020a, b). This may be due to the fact that the quercetin binds to either the COVID-19 spike protein at its host receptor region or the spike protein of the human angiotensin-converting enzyme 2 (ACE2) receptor interface, inhibiting the virus entry to cells and disrupting host-virus interactions indicating its therapeutic potential (Smith and Smith 2020).

The recommended consumption of flavonoids varies from 250 to $400 \mathrm{mg} /$ day (Peluso and Palmery 2015). Foods, like tea, cherries, berries, apples and citrus fruits, are the main sources of flavonoids. As well as that, onion and green leafy vegetables are rich in dietary flavonoids (Table 1) (Waheed Janabi et al. 2020).

\section{Perspectives and Future Directions}

Several clinical data have illustrated that there is a relationship between dietary supplements and COVID-19-associated coagulopathy, disrupted immune response and mortality, reduced platelet count and prolonged prothrombin time, suggesting there are benefits from supplementation.

Very little research has been conducted on, for example, the side effects of an overdosage of lipid soluble vitamins, namely vitamin $\mathrm{D}$ and vitamin $\mathrm{E}$, and the usage of the correct dose of some menials to prevent the development of the conditions listed above, which occur secondary to COVID-19. The incorrect dose of treatment might cause harm instead of aiding recovery. To understand more about these points, further randomized clinical studies are needed, to investigate the clear potential impacts of these kinds of effects on COVID-19.

\section{Conclusions}

In conclusion, this review has demonstrated that micronutrients act as an immune system booster; they can be a treatment option for those who choose not to take medications. The deficiency of micronutrients causes disorder in the immune system. It recommends that consuming foods rich in vitamins $\mathrm{C}, \mathrm{D}$ and $\mathrm{E}$ and minerals like zinc could provide a better lifestyle that can enhance immunity to help fight the diseases caused by bacteria, viruses and parasites. Several studies have suggested flavonoids as potential inhibitors of COVID-19 transmission. It has been found that there are strong links among vitamins $\mathrm{C}, \mathrm{D}$ and $\mathrm{E}$, zinc and flavonoids in improving the immune system. This can lead to protection of individuals and populations against developing a severe disease which thus has an impact on the COVID-19 disease process. With these proven relationships, it would be beneficial for dietary recommendations to be put in place throughout this pandemic to reduce the prevalence of deficiencies of these chemicals. This will ensure that chances of severe disease are reduced and more pivotally chances of survival are boosted.

Author contribution MA, AH and JM designed the study. MA and JM performed the research method. MA and AH analysed the data. MA wrote the paper with input from all authors. All authors discussed the results and contributed to the final manuscript.

Open Access This article is licensed under a Creative Commons Attribution 4.0 International License, which permits use, sharing, adaptation, distribution and reproduction in any medium or format, as long as you give appropriate credit to the original author(s) and the source, provide a link to the Creative Commons licence, and indicate if changes 
were made. The images or other third party material in this article are included in the article's Creative Commons licence, unless indicated otherwise in a credit line to the material. If material is not included in the article's Creative Commons licence and your intended use is not permitted by statutory regulation or exceeds the permitted use, you will need to obtain permission directly from the copyright holder. To view a copy of this licence, visit http://creativecommons.org/licenses/by/4.0/.

\section{References}

Adolfsson O, Huber BT, Meydani SN (2001) Vitamin E-enhanced IL-2 production in old mice: naive but not memory $\mathrm{T}$ cells show increased cell division cycling and IL-2-producing capacity. J Immunol 167:3809-3817. https://doi.org/10.4049/jimmunol. 167.7.3809

Agnew UM, Slesinger TL (2021) Zinc toxicity. In: StatPearls. Treasure Island (FL): StatPearls Publishing; Available from: https://www. ncbi.nlm.nih.gov/books/NBK554548/. Accessed 28 Apr 2021

Ahmed MH, Hassan A (2020) Dexamethasone for the treatment of coronavirus disease (COVID-19): a review. SN Compr Clin Med 2:2637-2646. https://doi.org/10.1007/s42399-020-00610-8

Ali MJ, Hanif M, Haider MA, Ahmed MU, Sundas F, Hirani A, Khan IA, Anis K, Karim AH (2020) Treatment options for COVID-19: a review. Front Med 7:480. https://doi.org/10.3389/fmed.2020. 00480

Ayoubkhani D, Khunti K, Nafilyan V, Maddox T, Humberstone B, Diamond I, Banerjee A (2021) Post-covid syndrome in individuals admitted to hospital with covid-19: retrospective cohort study. BMJ 372:n693. https://doi.org/10.1136/bmj.n693

Bhatia A (2021) Role of drugs in COVID 19 patient: a review. J Pharm Res Int 33:99-105. https://doi.org/10.9734/jpri/2021/v33i36A319 31

Biancatelli RMLC, Berrill M, Catravas JD, Marik PE (2020a) Quercetin and vitamin $C$ : an experimental, synergistic therapy for the prevention and treatment of SARSCoV-2 related disease (COVID19). Front Immunol 11:1451. https://doi.org/10.3389/fimmu.2020. 01451

Biancatelli RMLC, Berrill M, Marik PE (2020b) The antiviral properties of vitamin C. Expert Rev Anti Infect Ther 18:99-101. https:// doi.org/10.1080/14787210.2020.1706483

Bishop E, Ismailova I, Dimeloe SK, Hewison M, Whit JH (2021) Vitamin D and immune regulation: antibacterial, antiviral, anti-inflammatory. JBMR Plus 5:e10405. https://doi.org/10.1002/jbm4.10405

Cai Y, Li YF, Tang LP, Tsoi B, Chen M, Chen H, Chen XM, Tan RR, Kurihara H, He RR (2015) A new mechanism of vitamin C effects on A/FM/1/47(H1N1) virus-induced pneumonia in restraintstressed mice. Biomed Res Int 2015:675149. https://doi.org/10. 1155/2015/675149

Calder PC, Carr AC, Gombart AF, Eggersdorfer M (2020) Optimal nutritional status for a well-functioning immune system is an important factor to protect against viral infections. Nutrients 12:1181. https://doi.org/10.3390/nu12041181

Camini FC, da Silva Caetano CC, Almeida LT, Magalhães CLB (2017) Implications of oxidative stress on viral pathogenesis. Arch Virol 162:907-917. https://doi.org/10.1007/s00705-016-3187-y

Castrillo JL, Carrasco L (1987) Action of 3-methylquercetin on poliovirus RNA replication. J Virol 61:3319-3321. https://doi.org/10. 1128/JVI.61.10.3319-3321.1987

Charoenngam N, Holick MF (2020) Immunologic effects of vitamin D on human health and disease. Nutrients 12:2097. https://doi.org/ 10.3390/nu12072097
Chinsembu KC (2020) Coronaviruses and nature's pharmacy for the relief of coronavirus disease 2019. Rev Bras Farmacogn 30:603621. https://doi.org/10.1007/s43450-020-00104-7

Chirumbolo S, Bjørklund G, Sboarina A, Vella A (2017) The role of vitamin $\mathrm{D}$ in the immune system as a pro-survival molecule. Clin Ther 39:894-916. https://doi.org/10.1016/j.clinthera.2017.03.021

Corman VM, Lienau J, Witzenrath M (2019) Coronaviren als ursache respiratorischer infektionen [Coronaviruses as the cause of respiratory infections]. Internist 60:1136-1145. https://doi.org/10. 1007/s00108-019-00671-5

Costela-Ruiz VJ, Illescas-Montes R, Puerta-Puerta JM, Ruiz C, Melguizo-Rodríguez L (2020) SARS-CoV-2 infection: the role of cytokines in COVID-19 disease. Cytokine Growth Factor Rev 54:62-75. https://doi.org/10.1016/j.cytogfr.2020.06.001

Cui J, Li F, Shi ZL (2019) Origin and evolution of pathogenic coronaviruses. Nat Rev Microbiol 17:181-192. https://doi.org/10.1038/ s41579-018-0118-9

Daneshkhah A, Agrawal V, Eshein A, Subramanian H, Roy HK, Backman V (2020) The possible role of vitamin D in suppressing cytokine storm and associated mortality in COVID-19 patients. Med Rxiv.https://doi.org/10.1101/2020.04.08.20058 578

Diniz LRL, Bezerra-Filho CSM, Fielding BC, de Sousa DP (2020) Natural antioxidants: a review of studies on human and animal coronavirus. Oxid Med Cell Longev 2020:3173281. https://doi. org/10.1155/2020/3173281

Eleonora C, Patrizia F, Piero G, Riccardo G, Roberto S, Aldo L (2011) Flavonoids: chemical properties and analytical methodologies of identification and quantitation in foods and plants. Nat Prod Res 25:469-495. https://doi.org/10.1080/14786419.2010.482054

Forchette L, Sebastian W, Liu T (2021) A comprehensive review of COVID-19 virology, vaccines, variants, and therapeutics. Curr Med Sci.https://doi.org/10.1007/s11596-021-2395-1

Ghinai I, McPherson TD, Hunter JC, Kirking HL, Christiansen D, Joshi K, Rubin R, Morales-Estrada S, Black SR, Pacilli M, Fricchione MJ, Chugh RK, Walblay KA, Ahmed NS, Stoecker WC, Hasan NF, Burdsall DP, Reese HE, Wallace M, Wang C, Moeller D, Korpics J, Novosad SA, Benowitz I, Jacobs MW, Dasari VS, Patel MT, Kauerauf J, Charles EM, Ezike NO, Chu V, Midgley CM, Rolfes MA, Gerber SI, Lu X, Lindstrom S, Verani JR, Layden JE, Illinois COVID-19 Investigation Team (2020) First known person-to-person transmission of severe acute respiratory syndrome coronavirus 2 (SARS-CoV-2) in the USA. Lancet 395:1137-1144. https://doi.org/10.1016/S0140-6736(20)30607-3

Gibson RS, King JC, Lowe N (2016) A review of dietary zinc recommendations. Food Nutr Bull 37:443-460. https://doi.org/10.1177/ 0379572116652252

Ginde AA, Blatchford P, Breese K, Zarrabi L, Linnebur SA, Wallace JI, Schwartz RS (2017) High-dose monthly vitamin D for prevention of acute respiratory infection in older long-term care residents: a randomized clinical trial. J Am Geriatr Soc 65:496-503. https:// doi.org/10.1111/jgs.14679

Godinho PIC, Soengas RG, Silva VLM (2021) Therapeutic potential of glycosyl flavonoids as anti-coronaviral agents. Pharmaceuticals 14:546. https://doi.org/10.3390/ph14060546

Grant WB, Lahore H, McDonnell SL, Baggerly CA, French CB, Aliano JL, Bhattoa HP (2020) Evidence that vitamin D supplementation could reduce risk of influenza and COVID-19 infections and deaths. Nutrients 12:988. https://doi.org/10.3390/nu12040988

Halliwell B, Gutteridge JM (2015) Free radicals in biology and medicine. Oxford University Press, New York. https://doi.org/10.1093/ acprof:oso/9780198717478.001.0001

Hemilä H, Chalker E (2019) Vitamin C can shorten the length of stay in the ICU: a meta-analysis. Nutrients 11:708. https://doi.org/10. 3390/nu11040708 
Hoang BX, Shaw G, Fang W, Han B (2020) Possible application of high-dose vitamin $\mathrm{C}$ in the prevention and therapy of coronavirus infection. J Glob Antimicrob Resist 23:256-262. https://doi.org/ 10.1016/j.jgar.2020.09.025

Institute of Medicine (2000) Panel on dietary antioxidants and related compounds (2000). National Academies Press (US), Washington (DC) Available from: https://www.ncbi.nlm.nih.gov/books/ NBK225480/

Institute of Medicine (2011) Dietary reference intakes for calcium and vitamin D. The National Academies Press, Washington, DC. https://doi.org/10.17226/13050

Jayawardena R, Sooriyaarachchi P, Chourdakis M, Jeewandara C, Ranasinghe $P$ (2020) Enhancing immunity in viral infections, with special emphasis on COVID-19: a review. Diabetes Metab Syndr 14:367-382. https://doi.org/10.1016/j.dsx.2020.04.015

Joachimiak M, Joachimiak P (2021) Zinc against COVID-19? Symptom surveillance and deficiency risk groups. PLoS Negl Trop Dis 15:e0008895. https://doi.org/10.1371/journal.pntd.0008895

Jothimani D, Kailasam E, Danielraj S, Nallathambi B, Ramachandran H, Sekar P, Manoharan S, Ramani V, Narasimhan G, Kaliamoorthy I, Rela M (2020) COVID-19: poor outcomes in patients with zinc deficiency. Int J Infect Dis 100:343-349. https://doi.org/10. 1016/j.ijid.2020.09.014

Jovic TH, Ali SR, Ibrahim N, Jessop ZM, Tarassoli SP, Dobbs TD, Holford P, Thornton CA, Whitaker IS (2020) Could vitamins help in the fight against COVID-19? Nutrients 12:2550. https://doi.org/ 10.3390/nu12092550

Kalantar-Zadeh K, Moore LW (2020) Impact of nutrition and diet on COVID-19 infection and implications for kidney health and kidney disease management. J Ren Nutr 30:179-181. https://doi.org/ 10.1053/j.jrn.2020.03.006

Khomich OA, Kochetkov SN, Bartosch B, Ivanov AV (2018) Redox biology of respiratory viral infections. Viruses 10:392. https://doi. org/10.3390/v10080392

Kieliszek M, Lipinski B (2020) Selenium supplementation in the prevention of coronavirus infections (COVID-19). Med Hypotheses 143:109878. https://doi.org/10.1016/j.mehy.2020.109878

Kim Y, Kim H, Bae S, Choi J, Lim SY, Lee N, Kong JM, Hwang Y-I, Kang JS, Lee WJ (2013) Vitamin C is an essential factor on the anti-viral immune responses through the production of interferon$\alpha / \beta$ at the initial stage of influenza A virus (H3N2) infection. Immune Netw 13:70-74. https://doi.org/10.4110/in.2013.13.2.70

Kim HA, Perrelli A, Ragni A, Retta F, De Silva TM, Sobey CG, Retta SF (2020) Vitamin D deficiency and the risk of cerebrovascular disease. Antioxidants 9:327. https://doi.org/10.3390/antiox9040 327

Kmietowicz Z (2020) Sixty seconds on... vitamin D. BMJ 371:m3872. https://doi.org/10.1136/bmj.m3872

Komolafe K, Komolafe TR, Fatoki TH, Akinmoladun AC, Brai B, Olaleye MT, Akindahunsi AA (2021) Coronavirus disease 2019 and herbal therapy: pertinent issues relating to toxicity and standardization of phytopharmaceuticals. Rev Bras Farmacogn 31:142161. https://doi.org/10.1007/s43450-021-00132-x

Kunutsor SK, Laukkanen JA (2020) Renal complications in COVID19: a systematic review and meta-analysis. Ann Med 52:345-353. https://doi.org/10.1080/07853890.2020.1790643

Lalani S, Poh CL (2020) flavonoids as antiviral agents for enterovirus A71 (EV-A71) [published correction appears in Viruses. Viruses 12:184. https://doi.org/10.3390/v12020184

Leal CM, Leitão SG, Sausset R, Mendonça SC, Nascimento PH, Cheohen CF, Esteves ME, da Silva ML, Gondim TS, Monteiro ME, Tucci AR (2021) Flavonoids from Siparuna cristata as potential inhibitors of SARS-CoV-2 replication. Rev Bras Farmacogn 31. https://doi.org/10.1007/s43450-021-00162-5

Liskova A, Koklesova L, Samec M, Smejkal K, Samuel SM, Varghese E, Abotaleb M, Biringer K, Kudela E, Danko J, Shakibaei M,
Kwon TK, Büsselberg D, Kubatka P (2020) Flavonoids in cancer metastasis. Cancers 12:1498. https://doi.org/10.3390/cancers120 61498

Madjid M, Safavi-Naeini P, Solomon SD, Vardeny O (2020) Potential effects of coronaviruses on the cardiovascular system: a review. JAMA Cardiol 5:831-840. https://doi.org/10.1001/jamacardio. 2020.1286

Maggini S, Pierre A, Calder PC (2018) Immune function and micronutrient requirements change over the life course. Nutrients 10:1531. https://doi.org/10.3390/nu10101531

Marcinowska-Suchowierska E, Kupisz-Urbańska M, Łukaszkiewicz J, Płudowski P, Jones G (2018) Vitamin D toxicity - a clinical pPerspective. Front Endocrinol 9:550. https://doi.org/10.3389/ fendo.2018.00550

McAdams M, Ostrosky-Frid M, Rajora N, Hedayati S (2021) Effect of COVID-19 on kidney disease incidence and management. Kidney 2:141-153. https://doi.org/10.34067/KID.0006362020

Mehta P, McAuley DF, Brown M, Sanchez E, Tattersall RS, Manson JJ (2020) COVID-19: consider cytokine storm syndromes and immunosuppression. Lancet 395:1033-1034. https://doi.org/10. 1016/S0140-6736(20)30628-0

Meng LQ, Yang FY, Wang MS, Shi BK, Chen DX, Chen D, Zhou Q, He QB, Ma LX, Cheng WL, Xing NZ (2018) Quercetin protects against chronic prostatitis in rat model through NF- $\mathrm{KB}$ and MAPK signaling pathways. Prostate 78:790-800. https://doi.org/10.1002/ pros. 23536

Messina G, Polito R, Monda V, Cipolloni L, Di Nunno N, Di Mizio G, Murabito P, Carotenuto M, Messina A, Pisanelli D, Valenzano A, Cibelli G, Scarinci A, Monda M, Sessa F (2020) Functional role of dietary intervention to improve the outcome of COVID-19: a hypothesis of work. Int J Mol Sci 21:3104. https://doi.org/10. 3390/ijms21093104

Meydani SN, Leka LS, Fine BC, Dallal GE, Keusch GT, Singh MF, Hamer DH (2004) Vitamin E and respiratory tract infections in elderly nursing home residents: a randomized controlled trial. JAMA 292:828-836. https://doi.org/10.1001/jama.292.7.828

Milman NT (2020) A review of nutrients and compounds, which promote or inhibit intestinal iron absorption: making a platform for dietary measures that can reduce iron uptake in patients with genetic haemochromatosis. J Nutr Metab 2020:7373498. https:// doi.org/10.1155/2020/7373498

Mossink JP (2020) Zinc as nutritional intervention and prevention measure for COVID-19 disease. BMJ Nutr Prev Health 2020:e000095. https://doi.org/10.1136/bmjnph-2020-000095

Mrityunjaya M, Pavithra V, Neelam R, Janhavi P, Halami PM, Ravindra PV (2020) Immune-boosting, antioxidant and anti-inflammatory food supplements targeting pathogenesis of COVID-19. Front Immunol 11:570122. https://doi.org/10.3389/fimmu.2020.570122

Muchtaridi M, Fauzi M, Khairul Ikram NK, Mohd Gazzali A, Wahab HA (2020) natural flavonoids as potential angiotensin-converting enzyme 2 inhibitors for anti-SARS-CoV-2. Molecules 25:3980. https://doi.org/10.3390/molecules25173980

Name JJ, Souza ACR, Vasconcelos AR, Prado PS, Pereira CPM (2020) Zinc, vitamin D and vitamin C: perspectives for COVID-19 with a focus on physical tissue barrier integrity. Front Nutr 7:606398. https://doi.org/10.3389/fnut.2020.606398

Nathens AB, Neff MJ, Jurkovich GJ, Klotz P, Farver K, Ruzinski JT, Radella F, Garcia I, Maier RV (2002) Randomized, prospective trial of antioxidant supplementation in critically ill surgical patients. Ann Surg 236:814-822. https://doi.org/10.1097/00000 658-200212000-00014

Nawsherwan, Khan S, Zeb F, Shoaib M, Nabi G, Ul Haq I, Xu K, Li H (2020) Selected micronutrients: an option to boost immunity against covid-19 and prevent adverse pregnancy outcomes in pregnant women: a narrative review. Iran J Public Health 49:20322043. https://doi.org/10.18502/ijph.v49i11.4717 
Nchioua R, Kmiec D, Müller JA, Conzelmann C, Groß R, Swanson CM, Neil SJD, Stenger S, Sauter D, Münch J, Sparrer KMJ, Kirchhoff F (2020) SARS-CoV-2 is restricted by zinc finger antiviral protein despite preadaptation to the low- $\mathrm{CpG}$ environment in humans. mBio 11:e01930-20. https://doi.org/10.1128/mBio. 01930-20

Niki E, Abe A (2019) Vitamin E: structure, properties and functions. In: Niki E (ed) Vitamin E: Chemistry and Nutritional Benefits. Royal Society of Chemistry pp. 1-11. https://doi.org/10.1039/ 9781788016216-00001

Owen KN, Dewald O (2021) Vitamin E toxicity. In: StatPearls. Stat Pearls Publishing, Treasure Island. https://www.ncbi.nlm.nih.gov/ books/NBK564373/. Accessed 19 May 2021

Peluso I, Palmery M (2015) Flavonoids at the pharma-nutrition interface: is a therapeutic index in demand? Biomed Pharmacother 71:102-107. https://doi.org/10.1016/j.biopha.2015.02.028

Péter S, Friedel A, Roos FF, Wyss A, Eggersdorfer M, Hoffmann K, Weber P (2015) A systematic review of global alpha-tocopherol status as assessed by nutritional intake levels and blood serum concentrations. Int J Vit Nutr Res 85:261-281. https://doi.org/10. 1024/0300-9831/a000281

Pludowski P, Holick MF, Grant WB, Konstantynowicz J, Mascarenhas MR, Haq A, Povoroznyuk V, Balatska N, Barbosa AP, Karonova T, Rudenka E, Misiorowski W, Zakharova I, Rudenka A, Łukaszkiewicz J, Marcinowska-Suchowierska E, Łaszcz N, Abramowicz P, Bhattoa HP, Wimalawansa SJ (2018) Vitamin D supplementation guidelines. J Steroid Biochem Mol Biol 175:125-135. https://doi.org/10.1016/j.jsbmb.2017.01.021

Ran L, Zhao W, Wang J, Wang H, Zhao Y, Tseng Y, Bu H (2018) Extra dose of vitamin $\mathrm{C}$ based on a daily supplementation shortens the common cold: a meta-analysis of 9 randomized controlled trials. Biomed Res Int 2018:1837634. https://doi.org/10.1155/2018/ 1837634

Rathnayake AD, Zheng J, Kim Y, Perera KD, Mackin S, Meyerholz DK, Kashipathy MM, Battaile KP, Lovell S, Perlman S, Groutas WC, Chang K-O (2020) Chang 3C-like protease inhibitors block coronavirus replication in vitro and improve survival in MERSCoV-infected mice. Sci Transl Med 12(557):5332. https://doi.org/ 10.1126/scitranslmed.abc5332

Read SA, Obeid S, Ahlenstiel C, Ahlenstiel G (2019) The role of zinc in antiviral immunity. Adv Nutr 10:696-710. https://doi.org/10. 1093/advances/nmz013

Rondanelli M, Miccono A, Lamburghini S, Avanzato I, Riva A, Allegrini P, Faliva MA, Peroni G, Nichetti M, Perna S (2018) Self-care for common colds: the pivotal role of vitamin D, vitamin $\mathrm{C}$, zinc, and echinacea in three main immune interactive clusters (physical barriers, innate and adaptive immunity) involved during an episode of common colds-practical advice on dosages and on the time to take these nutrients/botanicals in order to prevent or treat or treat common colds. Evid Based Complement Alternat Med 2018:5813095. https://doi.org/10.1155/2018/5813095

Rungsung S, Singh TU, Rabha DJ, Kumar T, Lingaraju MC, Parida S, Paul A, Sahoo M, Kumar D (2018) Luteolin attenuates acute lung injury in experimental mouse model of sepsis. Cytokine 110:333-343. https://doi.org/10.1016/j.cyto.2018.03.042

Russo M, Moccia S, Spagnuolo C, Tedesco I, Russo GL (2020) Roles of flavonoids against coronavirus infection. Chem Biol Interact 328:109211. https://doi.org/10.1016/j.cbi.2020.109211

Sahin E, Orhan C, Uckun FM, Sahin K (2020) Clinical impact potential of supplemental nutrients as adjuncts of therapy in high-risk COVID-19 for obese patients. Front Nutr 7:580504. https://doi. org/10.3389/fnut.2020.580504

Saura M, Zaragoza C, McMillan A, Quick RA, Hohenadl C, Lowenstein JM, Lowenstein CJ (1999) An antiviral mechanism of nitric oxide: inhibition of a viral protease. Immunity 10:21-28. https:// doi.org/10.1016/S1074-7613(00)80003-5
Sette A, Crotty S (2021) Adaptive immunity to SARS-CoV-2 and COVID-19. Cell 184:861-880. https://doi.org/10.1016/j.cell. 2021.01.007

Shakoor H, Feehan J, Al-Dhaheri AS, Ali HI, Carine P, Cheikh Ismail L, Apostolopoulos V, Stojanovska L (2021) Immune-boosting role of vitamins D, C, E, zinc, selenium and omega-3 fatty acids: could they help against COVID-19? Maturitas 143:1-9. https://doi.org/ 10.1016/j.maturitas.2020.08.003

Sharrock J (2019) Natural killer cells and their role in immunity. EMJ Allergy Immunol 4:108-116 https://www.emjreviews.com/aller gy-immunology/article/natural-killer-cells-and-their-role-inimmunity/

Siddiqi HK, Mehra MR (2020) COVID-19 illness in native and immunosuppressed states: a clinical-therapeutic staging proposal. J Heart Lung Transpl 39:405-407. https://doi.org/10.1016/j.healun. 2020.03.012

Singh R, Shaik L, Mehra I, Kashyap R, Surani S (2020) Novel and controversial therapies in COVID-19. Open Respir Med J 14:79-86. https://doi.org/10.2174/1874306402014010079

Skalny AV, Rink L, Ajsuvakova OP, Aschner M, Gritsenko VA, Alekseenko SI, Svistunov AA, Petrakis D, Spandidos DA, Aaseth J, Tsatsakis A, Tinkov AA (2020) Zinc and respiratory tract infections: perspectives for COVID-19 (Review). Int J Mol Med 46:1726. https://doi.org/10.3892/ijmm.2020.4575

Smith M, Smith JC (2020) Repurposing therapeutics for COVID-19: supercomputer-based docking to the SARSCoV-2 viral spike protein and viral spike protein-human ACE2 interface. ChemRxiv Cambridge: Cambridge Open Engage; This content is a preprint and has not been peer-reviewed. https://doi.org/10.26434/chemr xiv.11871402.v2

Steven JF, Daniel SK, Marina SH, Qian X, Kathy K (2018) Griendling reactive oxygen species in metabolic and inflammatory signaling. Circ Res 122:877-902. https://doi.org/10.1161/CIRCRESAHA. 117.311401

Stubbs JR, Zhang S, Friedman PA, Nolin TD (2014) Decreased conversion of 25-hydroxyvitamin D3 to 24,25-dihydroxyvitamin D3 following cholecalciferol therapy in patients with CKD. Clin J Am Soc Nephrol 9:1965-1973. https://doi.org/10.2215/CJN.03130314

Suzuki M, Suzuki T, Watanabe M, Hatakeyama S, Kimura S, Nakazono A (2021) Role of intracellular zinc in molecular and cellular function in allergic inflammatory diseases. Allergol Int 70:190-200. https://doi.org/10.1016/j.alit.2020.09.007

te Velthuis AJW, van den Worm SHE, Sims AC, Baric RS, Snijder EJ, van Hemert MJ (2010) Zn2+ Inhibits coronavirus and arterivirus RNA polymerase activity in vitro and zinc ionophores block the replication of these viruses in cell culture. PLoS Pathog 6:e1001176. https://doi.org/10.1371/journal.ppat.1001176

Traber MG, Atkinson J (2007) Vitamin E, antioxidant and nothing more. Free Radic Biol Med 43:4-15. https://doi.org/10.1016/j. freeradbiomed.2007.03.024

Traber MG, Stevens JF (2011) Vitamins C and E: beneficial effects from a mechanistic perspective. Free Radic Biol Med 51:10001013. https://doi.org/10.1016/j.freeradbiomed.2011.05.017

Uwitonze AM, Razzaque MS (2018) Role of magnesium in vitamin $\mathrm{D}$ activation and function. J Am Osteopath Assoc 118:181-189. https://doi.org/10.7556/jaoa.2018.037

van Acker SA, Tromp MN, Haenen GR, van der Vijgh WJ, Bast A (1995) Flavonoids as scavengers of nitric oxide radical. Biochem Biophys Res Commun 214:755-759. https://doi.org/10.1006/bbrc. 1995.2350

Vorilhon P, Arpajou B, Vaillant Roussel H, Merlin É, Pereira B, Cabaillot A (2019) Efficacy of vitamin $C$ for the prevention and treatment of upper respiratory tract infection. A meta-analysis in children. Eur J Clin Pharmacol 75:303-311. https://doi.org/10. 1007/s00228-018-2601-7 
Vrijsen R, Everaert L, Van Hoof LM, Vlietinck AJ, Vanden Berghe DA, Boeyé A (1987) The poliovirus-induced shut-off of cellular protein synthesis persists in the presence of 3-methylquercetin, a flavonoid which blocks viral protein and RNA synthesis. Antiviral Res 7:35-42. https://doi.org/10.1016/0166-3542(87)90037-4

WaheedJanabi AH, Kamboh AA, Saeed M, Xiaoyu L, BiBi J, Majeed F, Naveed M, Mughal MJ, Korejo NA, Kamboh R, Alagawany M, Huixia L (2020) Flavonoid-rich foods (FRF): a promising nutraceutical approach against lifespan-shortening diseases. Iran J Basic Med Sci 23:140-153. https://doi.org/10.22038/IJBMS. 2019.35125.8353
Wessels I, Maywald M, Rink L (2017) Zinc as a gatekeeper of immune function. Nutrients 9:1286. https://doi.org/10.3390/nu9121286

Zalewski PD, Truong-Tran AQ, Grosser D, Jayaram L, Murgia C, Ruffin RE (2005) Zinc metabolism in airway epithelium and airway inflammation: basic mechanisms and clinical targets. A review. Pharmacol Ther 105:127-149. https://doi.org/10.1016/j.pharm thera.2004.09.004

Zhang Y, Geng X, Tan Y, Li Q, Xu C, Xu J, Hao L, Zeng Z, Luo X, Liu F, Wang H (2020) New understanding of the damage of SARSCoV-2 infection outside the respiratory system. Biomed Pharmacother 127:110195. https://doi.org/10.1016/j.biopha.2020.110195 